\title{
Opening session
}

INTRODUCTION OF THE SYMPOSIUM

dedicated to the memory of Einar Tandberg Hanssen 


\section{Einar Tandberg-Hanssen}

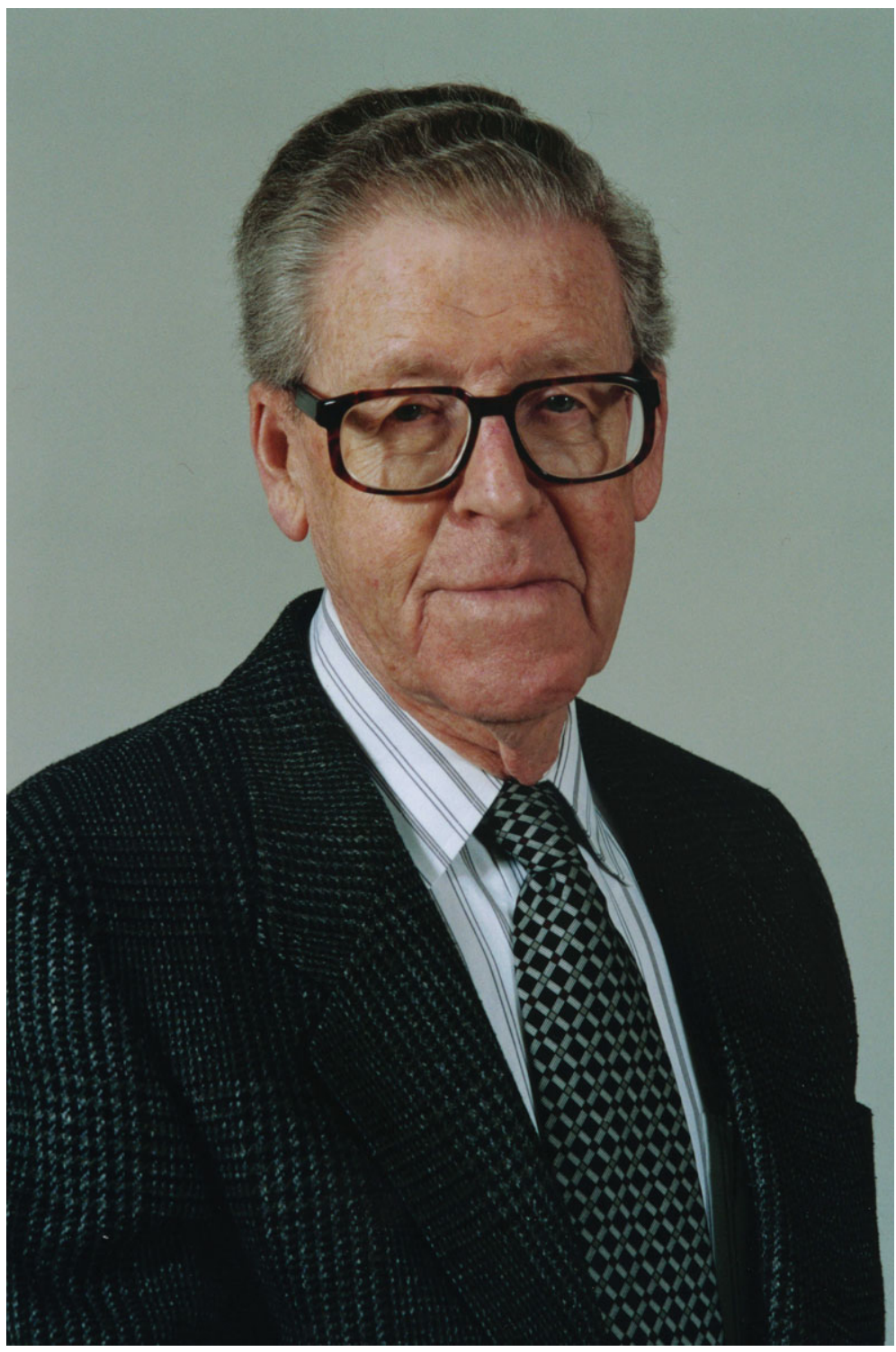

Figure 1. Einar Tandberg-Hanssen portrait (@Julia Gary). 